\author{
S. Kolesnikov, \\ PhD (Physico-mathematical), \\ Associate Professor, \\ ORCID 0000-0002-9538-8858, \\ V. Mishura, \\ PhD (Economics), \\ Associate Professor,
}

Donbass State Engineering Academy, Kramatorsk

\title{
DEVELOPMENT OF THE AGRARIAN SECTOR OF THE UKRAINIAN ECONOMY: FORECASTS AND PROSPECTS
}

Formulation of the problem. The agrarian sector is one of the most important sectors of the national economy, covering various types of economic activity in the production of agricultural products, foodstuffs, as well as delivery to the final consumer. Processes of institutional change in the agricultural sector of the economy Ukraine is currently one of the most important elements of sustainable development of the country and its regions, enhancing its competitiveness, and strengthening national security. In recent years, the agrarian sector of Ukraine has shown positive dynamics and increased production of agricultural products.

Research of problems and prospects of development of agrarian sector of economy of Ukraine will allow to form sectoral directions of increase of competitiveness in the context of ensuring sustainable economic growth of the agricultural sector on the principles of innovation. At the present stage of development of the agricultural sector of the national economy, the issues of development of agroholdings and their impact on sectoral competitiveness are relevant.

Analysis of recent research. Well-known scientists, such as A. Borodin [1], I. Kirilenko [2], Yu. Lupenko [3], V. Messel-Veselyak [4], P. Sabluck [5] and others. They substantiated the need to create a favorable institutional and market environment in the process of market transformation, determined the appropriate methods, forms and level of state support for agricultural producers, areas of financial and tax and investment policies in the field, etc.

Scientific generalization of problems of state agrarian policy, support of agricultural producers in Ukraine was reflected in the works of T. Zinchuk [6], T. Kalashnikova [7], S. Kvashi [8], O. Popova [9], N. Shibaeva [10] and many others. But changes in the conditions of development of the agrarian sector, its state support, require scientific generalizations that would reflect a scientifically grounded assessment of the current state and identify the main vectors for the necessary transformation of agrarian policy.

The purpose of the article is to determine the prospects for the development of the agricultural sector of the national economy, taking into account the existing risks and possible options for public policy at the current stage of institutional change.

Outline of the main research material. The emergence and development of institutionalism as a direction of the general economic theory was objectively conditioned by the development of productive forces and industrial relations, the division of social labor, and as a result of the development of intra-industry and inter-industry cooperation of agricultural producers, processing industries and supply systems.

Institutional transformations in the agrarian sector of the economy mean a way of removing contradictions between the requirements of the market and the logic of behavior of economic entities, which consists in the implementation of organizational-economic, financialeconomic, legal and technical measures aimed at reorganization of enterprises, change of ownership, management, legal form that will contribute to the financial recovery of the economy, increase the volume of competitive products, increase production efficiency [11, p. 10].

This, in turn, leads to the integration of production, the emergence in Ukraine and its regions of not only small and medium-sized enterprises, but also large companies, and not only national, but also transnational scale, market monopolization, development and complication of intra-industry and inter-industry links. of languages and relationships.

The process of agricultural production, from the initial stages to the consumer, must be organized in some space and time. This kind of organization happens through the creation of businesses. Entrepreneurs - natural persons may also satisfy the market needs for these products.

The essence of the enterprise as an organizational form of economic activity is defined by the Economic Code of Ukraine (Article 62): the enterprise is an independent economic entity created by a competent state authority or local self-government body or other entities to meet social and personal needs through systematic production, research, trade, other economic activity in the manner provided by this Code and other laws [13]. 
According to the current legislation of Ukraine provides for the functioning of state, communal and private property. According to the basic law, depending on the forms of ownership, the Economic Code of Ukraine provides for the functioning of enterprises, incl. and agricultural, the following types:

- a private enterprise operating on the basis of private property of a citizen or business entity (legal entity);

- enterprise operating on the basis of collective ownership;

- communal enterprise operating on the basis of communal property of a territorial community;

- state-owned enterprise operating on the basis of state ownership;
- an enterprise based on a mixed form of ownership (on the basis of combining property of different forms of ownership) [13].

Thus, in the field of agriculture, entrepreneurial structures of all the above types can be created and operated. In turn, economic entities of different organizational and legal forms are constantly created and functioning in the agricultural sector of Ukraine. The general and special conditions for their creation are determined by the legislation. In recent years, the share of agricultural entities in the agricultural sector has been about $4 \%$ of the total number of entities, with enterprises accounting for the lion's share. There are four main groups of agricultural producers in Ukrainian agriculture (Fig. 1) [14].

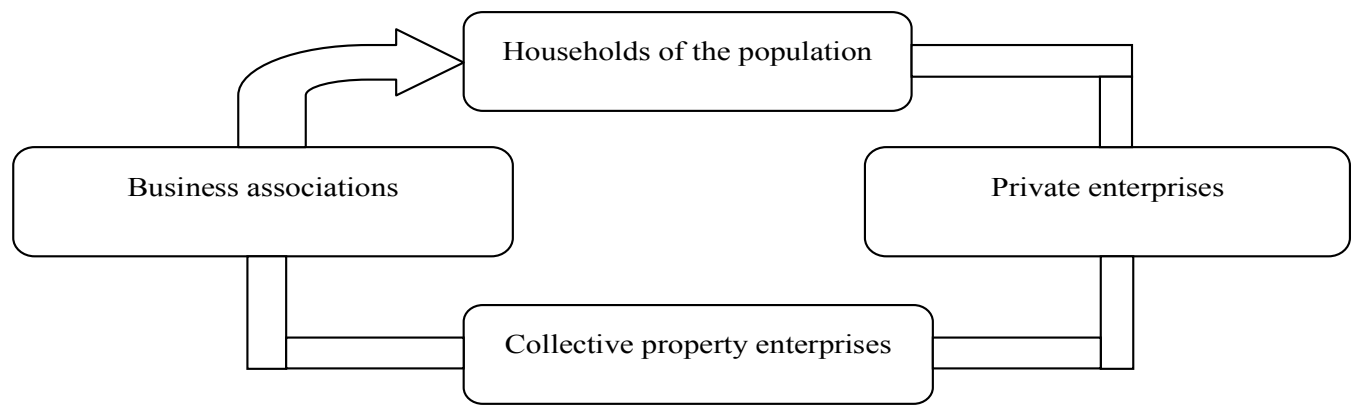

Fig. 1. Groups of agricultural producers [14]

Each group of agricultural producers has its own peculiarities, conditions of operation and prospects for development.

1. Households (including also entrepreneurs) are non-legal entities and grow agricultural products both for their own use and for sale. Such farms specialize in the commercial cultivation of vegetables and other niche crops, which is difficult to grow on an industrial scale because of the need for manual labor.

2. Private enterprises in agriculture are represented by farms and private agricultural enterprises.

Farms can only be created by Ukrainian citizens, and their activities should be based on the work of the family members of the farmer, although employment is permitted. The land can belong to the farmer both on the property and for rent. Farm areas can also vary from a few hectares to five to ten thousand hectares, which is actually a full-fledged medium-sized enterprise. More than $60 \%$ of farms have an area of 100 to 2000 thousand hectares.

Private agricultural enterprises are legal entities that operate on the basis of private property and may be founded by citizens of Ukraine, as well as foreigners, stateless persons and legal entities.

They are governed by the general rules of the Civil and Commercial Codes for conducting business.

3. Enterprises of collective ownership, various forms of cooperatives. Cooperatives in Ukraine can be of different types. The most common of these are production and service cooperatives.
Production cooperative - is formed exclusively by natural persons for joint production or other economic activity on the basis of their compulsory labor participation for the purpose of profit.

Serving cooperative - formed by individuals and / or legal entities for the provision of services mainly to members of the cooperative, as well as to other persons for the purpose of conducting their economic activities.

4. Businesses can be either national or foreign or with foreign investment.

In the agricultural sector, business is the most common form of business after farming. They are presented mainly in the form of limited liability companies and joint stock companies.

Limited Liability Company (LLC) is an enterprise created on the basis of an agreement between legal entities and / or citizens by combining their property and business for profit. LLC has a statutory fund divided into shares in the amounts specified in the constituent documents - the charter.

The law does not set a minimum number of LLC members, but the maximum number of participants may not exceed one hundred.

Joint Stock Companies (JSC). The authorized capital of AO is divided into a certain number of shares of equal par value, and the shareholders are liable for the obligations of the company only within the limits of their shares. 
The founders of the joint-stock company can be both individuals and legal entities. AOs are divided into two types: open and closed AOs.

Open Joint Stock Company means that its shares can be distributed through open subscription and sale on the exchanges. In Closed JSC, the shares are solely distributed among the founders and cannot be distributed by subscription, bought and sold on the stock exchange. A closed joint stock company may be reorganized into a public limited company by amending the articles of association [13].

Having considered the mentioned organizational and legal forms of agriculture. enterprises, we can conclude that the first three types of organizational forms are more typical for small and medium-sized agricul- tural producers and are rarely used to attract foreign investment. Limited Liability Companies (LLCs) and Joint Stock Companies (JSCs) are the most common and can be both small and large enterprises and are more convenient and attractive for attracting investment.

The largest agricultural producers choose the holding structure of the organization and place their shares on world stock exchanges [13].

Speaking about the peculiarities of functioning of agrarian entrepreneurship in market conditions, let us pay attention to the analytics, that is, the economy of representation of economic entities of the agrarian profile in the economy of Ukraine. The main economic entities in agriculture are agricultural enterprises, the tendency of which changes during 2013-2017 are shown in Table 1 and Fig. 2.

Dynamics of changes in the number of agricultural enterprises in Ukraine during 2012-2018

Table 1 (developed by the authors based on source [14])

\begin{tabular}{|l|c|c|c|c|c|c|c|c|}
\hline \multirow{2}{*}{ Indicator } & \multicolumn{7}{|c|}{ Years } & $\begin{array}{c}\text { Deviation } \\
(+;-), \\
2018 / 2012\end{array}$ \\
\cline { 2 - 9 } & 2012 & 2013 & 2014 & 2015 & 2016 & 2017 & 2018 & +1026 \\
\hline $\begin{array}{l}\text { Agricultural } \\
\text { enterprises, units }\end{array}$ & 48632 & 49046 & 46199 & 45379 & 47697 & 45558 & 49658 & +1026 \\
\hline $\begin{array}{l}\text { of these are farming } \\
\text { farms }\end{array}$ & 33093 & 34168 & 33084 & 32303 & 33682 & 34137 & 37209 & +4116 \\
\hline
\end{tabular}

Analyzing the analytical indicators of changes in the number of agricultural enterprises during 20122018 , it was found that the number of agricultural enterprises in 2017 compared to 2013 decreased by 3488 entities (of which farms decreased by 31 units). However, in comparison with 2016 in 2017, the number of agricultural entities decreased by 2139 units, which in turn is lower than in 2013. However, for 5 years, the number of agricultural enterprises cannot reach 2013 (49046 units). The share of agricultural production in the main categories of farms in Ukraine in 2016 was agricultural enterprises $57.0 \%$, households $43.0 \%$, by region agricultural enterprises produced more than 50\% Vinnytsia, Dnipropetrovsk, Zaporizhia, Kyiv, Kirovohrad, Mykolaiv, Odesa, Poltava, Sumy, Ternopil, Kharkiv, Kherson, Khmelnitsky, and Chernihiv and Cherkasy respectively 70,2, 75,9\%. However, the Volyn, Lviv, Rivne, Ivano-Frankivsk, Chernivtsi, Transcarpathian regions share of the population is $60.8,64.1,66.4,68.8$, respectively. 78.6, 91.0 percent [12, p. 56].

We will carry out a correlation analysis of farms and non-farms for the period from 2012 to 2018. Denote the $X$ - number of farms; $Y$ - number of non-farms. The obtained pairwise regression equation leads us to believe that the relationship between all possible values of $X$ and $Y$ is linear $y=b x+a$. Thus, the dependence of $Y$ on $X$ was studied. In the specification step, a pairwise linear regression was chosen. It estimated its least squares parameters.
Regression equation (empirical regression equation): $y=-0.375 \cdot x+38996$.

Coefficient of linear paired correlation: $r_{x, y}=-0,322$.

In our example, the relationship between $Y$ and factor $X$ is moderate and inverse. The statistical significance of the equation is verified using the Fisher coefficient and determination. It is established that in the investigated situation only $10.35 \%$ of the total variability $Y$ is explained by the change in $X$. The statistical insignificance of the model is due to the small sample size and the influence of other factors on the resultant factor $U$.

A possible economic interpretation of the model parameters is an increase of $X$ per 1000 units. leads to a decrease in $Y$ by an average of 375 units. The quality of the regression equation was estimated using the absolute approximation error. The average error of approximation is the average deviation of the calculated values from the actual ones in our task $2.99 \%$. Since the error is less than $7 \%$, this equation can be used as a regression and in economic calculations, for example in forecasting. With a farm average of $x=13460$, the number of non-farms $(y=33948)$ will be in the range of 29450 to 38457 units. $95 \%$ will probably not go beyond those limits. The current situation is characterized by a narrowing of the financial base for the development of ag- 
ricultural production. There remains a likelihood of diminishing sources of formation of agricultural producers' own financial resources due to unfavorable price conditions for the main types of mineral fertilizers consumed, logistical products, plant protection products and restraining the rise in prices for agricultural products. If prices rise at the level of forecast macroeconomic indicators in 2015 , the profitability will be $6.7 \%$ (profit of 11.3 billion UAH).

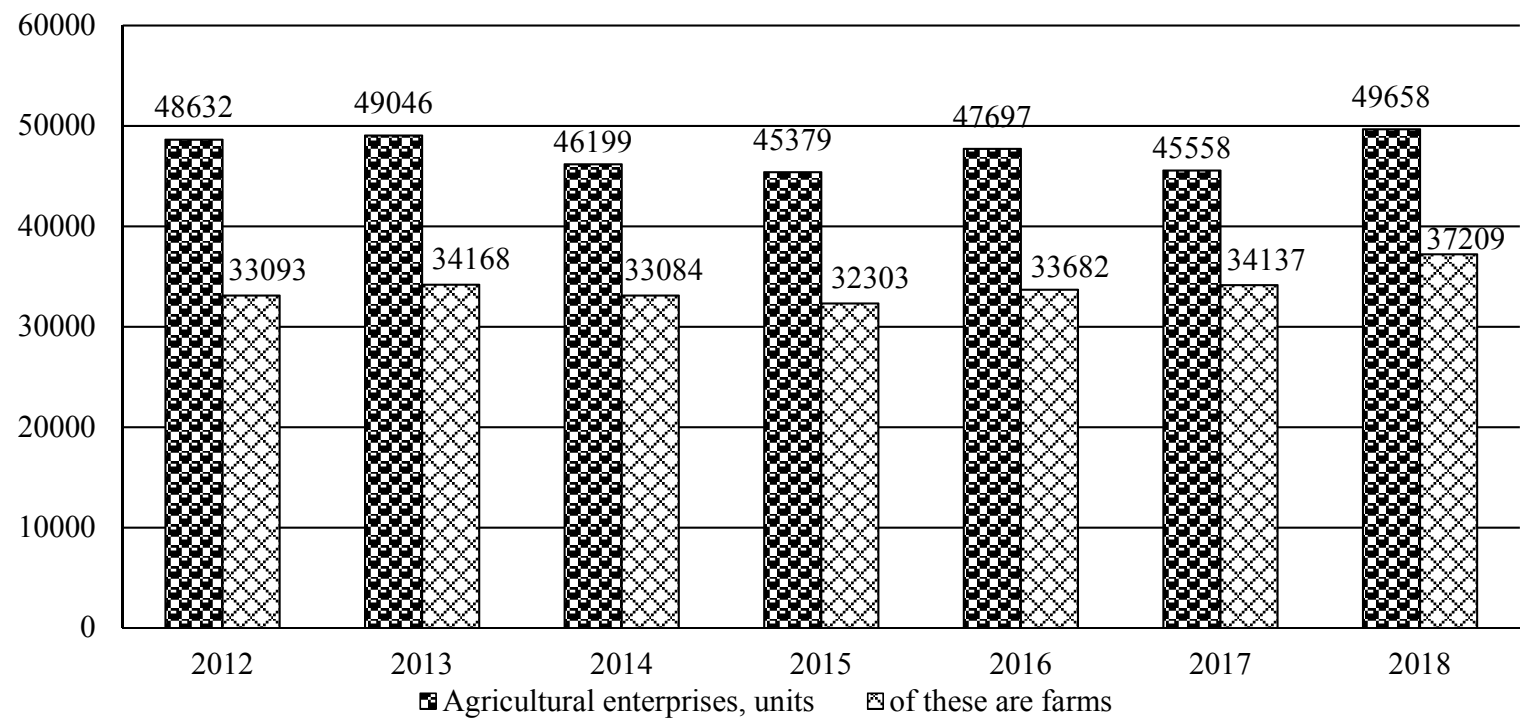

Fig. 2. Dynamics of changes in the number of agricultural enterprises in Ukraine during 2012-2018 (developed by the authors on the basis of source [14])

Therefore, it is projected to reduce the volume of sources of formation of own funds of agricultural enterprises by $20-25 \%$, with their absolute value of $40-50$ billion UAH. The volume of receipts for agricultural production of credit resources is projected at the level of 7 billion UAH, and under the optimistic scenario -8.5 billion UAH. Compared to the previous year, the annual volume of bank loans can decrease by $30.0 \%$. However, if the state targeted financial support program is renewed through a mechanism of cheaper loans of 300 million UAH, agricultural production may additionally attract about 10 billion UAH of credit resources, the cost of which will be reduced by 3-4 percentage points [14].

To increase the volume and efficiency of financial and credit support of agriculture, it is necessary to:

- to form a system of financial and credit servicing of agricultural producers, to expand its infrastructure components;

- to renew the action of state programs to support crediting of agricultural producers;

- improve the micro-credit system, especially for small businesses;

- Expand the system of credit protection insurance.

Minimizing the risk of loss of income is facilitated by the use of agrarian instruments of agricultural insurance. However, due to the lack of a quality system of agricultural insurance and state support, the dynamics of the insurance market may deteriorate: the number of insurance contracts will decrease by $11 \%$, the amount of premiums collected will increase by $12-13 \%$, the level of payments will be at the level of $8-9 \%$. The agricultural insurance market covers only about $5 \%$ of agricultural business entities.

In order to maintain the positive trends of agricultural insurance development and to improve the insurance protection of agricultural producers, according to the Agricultural Insurance Reform Roadmap, it is necessary to:

- to create a qualitative system of insurance protection of agricultural producers with the expansion of its institutional components;

- to renew the validity of state programs for partial compensation of insurance premiums for agricultural producers;

- improve the requirements for entry of insurers into profile associations;

- to introduce underwriting, loss settlement and reinsurance under all standard programs with state support;

- Improve the guarantee mechanism for insurers to fulfill their obligations to agricultural producers.

Given the difficult economic and military-political situation, further cuts in budget financing for the development of agro-industrial production are likely, which will not have catastrophic consequences, given the selectivity of this form of support and its low volumes in previous years. Measures of price regulation and credit support (within the framework of forward purchases and granting of a credit subsidy) will have the greatest influence on the development of agro-industrial production. 
The amount of budget financing for agro-industrial development programs on an irrevocable basis is envisaged in the amount of UAH 0.47 billion, of which UAH 0.3 billion is planned to be allocated for credit subsidies, over UAH 0.1 billion is for measures on state price regulation of the agrarian market (first of all, the market grain and flour).

Financial support on a rotating basis is envisaged to the amount of UAH 1.43 billion - almost entirely for the formation of the State Intervention Fund and other activities of the Agrarian Fund. This amount of financing will not be sufficient to properly stimulate the processes of satisfying the credit needs of agricultural enterprises and to fulfill the regulatory tasks of the Agrarian Fund.

At the same time, the prospect of termination of the special VAT regime in the future will deprive the livestock industry of nearly 2 billion UAH of additional financial resources, which were formed both directly in processing enterprises and in the special fund of the State Budget of Ukraine. This will have a negative impact on the level of prices for livestock products (primarily milk and cattle) and can lead to a significant decrease in the livestock population, especially in households. Non-reimbursement of value added tax to grain exporters will result in the withdrawal of financial resources from this segment of the agricultural market in the amount of over UAH 10.5 billion. Tax burden will increase by more than 20 times per 1 ha of agricultural land with payment of a single tax by the payers of the fourth group. The issue of levying property tax on agricultural producers remains unsettled - both in the part of the taxation of buildings and structures not directly used in the conduct of agricultural activity, and of land tax for land under administrative buildings. Deprivation of research farms, educational establishments and scientific institutions of privileges for payment of the land tax which rates by the decision of local councils can in- crease several times against the level of the previous year will have a negative impact. A serious challenge to the sustainability of the industry is the reduction in the number of small (primarily farmers) businesses. The rapid decline in the level of incomes of domestic consumers is holding back the rate of increase in prices in the domestic agri-food markets. At the same time, small agricultural producers are more vulnerable in the conditions of rising prices for the means of production and deteriorating financial support for the industry. Here are some specific ways to develop agrarian entrepreneurship in Ukraine:

- improving the institutional environment of small business forms in order to form a middle class in the countryside and maintain competition in the agricultural and food markets;

- ensuring equal access to resources and state support for all business entities, regardless of ownership and size;

- improvement of crop rotation structure and introduction of the use of organic fertilizers producers;

- solving of personnel problems, increasing the number of highly qualified personnel;

- updating of the material and technical base;

- improvement of the system of management and organization of industrial relations.

Thus, further development of agribusiness in the agricultural sector will contribute to improving the efficiency of agricultural production in the country. State support for agriculture in Ukraine is not only unstable (The expenditures of the State Budget under the Ministry of Agrarian Policy in 2008-2018 are shown in Fig. 3, but are significantly lower than the leading exporters of agricultural products. OECD experts estimate that farmers' support was even negative. In 2015, it accounted for $2.23 \%$ of GDP and $9.5 \%$ of total agrarian income for the PSE. In the OECD countries, farmers received, on average, $16 \%$ of total income in 2014-2016.

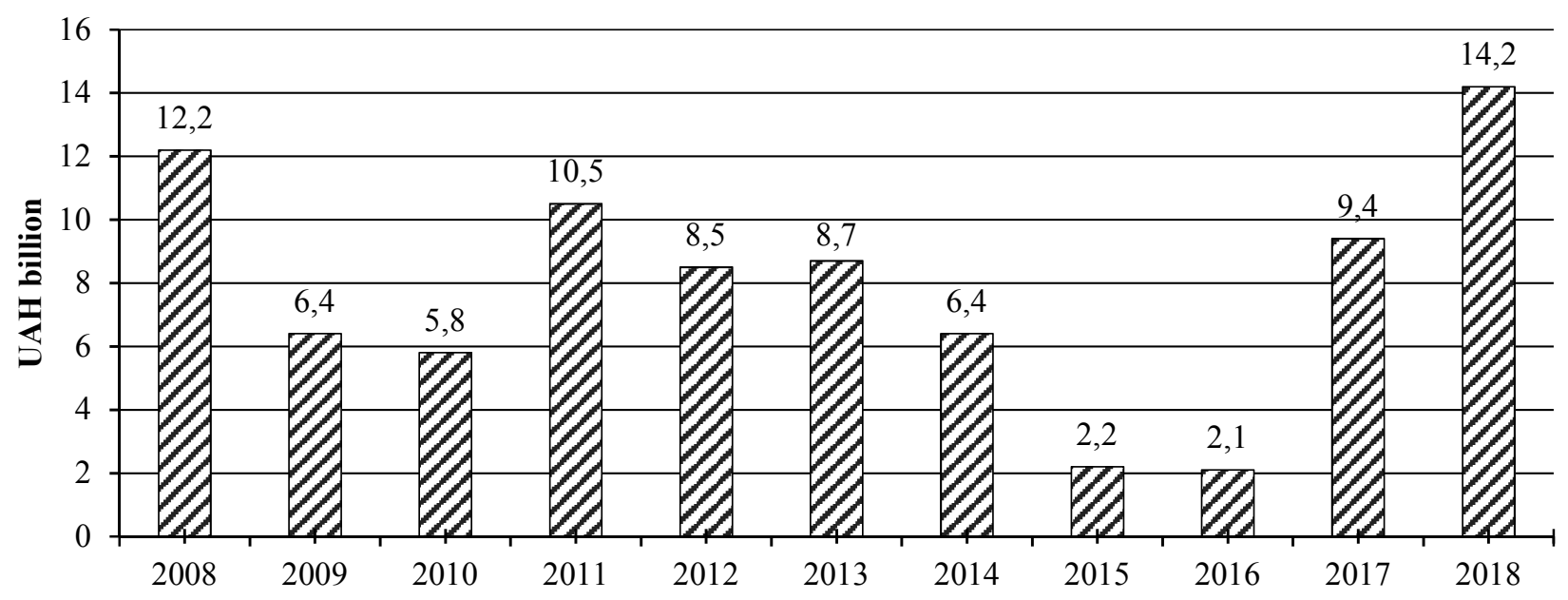

Fig. 3. Planned expenditures of the State Budget of Ukraine for the Ministry of Agrarian Policy of Ukraine, billion UAH (compiled by source [15]) 
The State Budget of Ukraine for 2018 provides for financial support for agricultural production of UAH 945 million. (Table 2), amounting to EUR 27.8 million, or EUR 1.4 per hectare of agricultural land (for comparison: in EU countries, this support amounts to EUR 200300 per hectare).

Table 2

\section{Distribution of budget expenditures on the Ministry of Agrarian Policy of Ukraine according to the program classification approved by the Law of Ukraine "On the State Budget of Ukraine for 2018"} (compiled by the authors on the basis of source [15])

\begin{tabular}{|l|c|}
\hline \multicolumn{1}{|c|}{ Costs } & ths. \\
\hline Ministry of Agrarian Policy and food of Ukraine, everything & 14154691,7 \\
\hline Financial support for activities in the agro-industrial complex through cheaper loans & 66000,0 \\
\hline $\begin{array}{l}\text { Research, applied scientific and technological development in the field of agro-industrial com- } \\
\text { plex }\end{array}$ & 132644,9 \\
\hline Improvement of qualification of specialists of agro-industrial complex & 21594,1 \\
\hline Financial support for activities in the agro-industrial complex & 5000,0 \\
\hline Financial support for the development of farms & 1000000,0 \\
\hline $\begin{array}{l}\text { Costs of the Agrarian Fund are related to the complex of measures for storage, transportation, } \\
\text { processing and export of objects of state price regulation of the state intervention fund }\end{array}$ & 52200,0 \\
\hline $\begin{array}{l}\text { Organization and regulation of activities of institutions in the system of agro-industrial complex } \\
\text { and provision of activities of the Agrarian Fund }\end{array}$ & 128409,0 \\
\hline $\begin{array}{l}\text { State support for, and supervision of, horticulture development, planting of young gardens, vine- } \\
\text { yards and berries }\end{array}$ & 300000,0 \\
\hline State support for animal husbandry & 4000000,0 \\
\hline Financial support for agricultural producers & 945000,0 \\
\hline
\end{tabular}

UAH 1 billion is also foreseen. financial support for the development of farms and UAH 4 billion. state support for animal husbandry. In response to this, and in order to determine the current state of affairs in the field, the Association of Cattle Breeders of Ukraine (official site https://usba.com.ua/) conducted a survey of 54 enterprises-producers of livestock products across Ukraine about the amount of funds they need for reconstruction and business expansion. The results of the survey showed that only these 54 enterprises need state funding for a total amount of over UAH 2048250000.

Therefore, modern state support for agricultural producers is not sufficient, consistent, stable, predictable, which significantly reduces the effectiveness of the measures implemented. Given the country's acute budget deficits, its limited amounts are understandable, and in such circumstances, the choice of strategic priorities for state support becomes crucial.

To ensure a rational level of compliance of agricultural producers with agro-technological requirements it is necessary to take a set of measures, in particular:

- to introduce a favorable import regime for imported mineral fertilizers and plant protection products;

- improve the organization of production of mineral fertilizers through fuller use of domestic phosphorites, deposits of which are in Rivne, Volyn, Ternopil, Sumy regions and potash ores of the Carpathian Potash Basin of Lviv and Ivano-Frankivsk regions, which will allow to reduce their prices accordingly;

- increase the volume of application of liquid nitrogen fertilizers (the value of nitrogen in liquid nitrogen fertilizers is 1.2-1.5 times lower than in ammonium nitrate);
- Introduce economic incentives for land owners, land users and land tenants to increase soil fertility and improve their economic condition.

Despite the prospects for the development of the agricultural sector in Ukraine, the reduction in the number of agricultural enterprises is influenced by national conditions. In particular:

- increase in the cost of cultivation of crops (hryvnia devaluation, volatile exchange rate cause fuel, fertilizer, etc.);

- staffing problems (lack of highly qualified personnel, despite the fact that every fifth Ukrainian works in the field of agriculture;

- difficulties with financing;

- degradation of agricultural land (violation of scientifically sound agricultural management systems, monoculture of agriculture) [9].

Also, the decrease in the number of agricultural enterprises is to some extent influenced by the characteristics of agriculture, which are related to the nature of its production, which is based on the ability of plant and animal organisms to natural reproduction, which depends on climate and soil. Particularly important public administration functions in the agrarian sector of the Ukrainian economy are to create conditions that will not only stimulate each producer to respond to consumer requests, but also force them to adapt to effective demand, timely adjust production volumes, improve consumer products.

Achieving this goal should be facilitated by the reform of the price mechanism in agriculture. Prices should reflect the level of public utility of the product, 
interact with the system of non-price levers of state support for agriculture. Analysis of the state of food security in Ukraine showed that in recent years the problem of food sufficiency has a structural aspect, and if the production of cereals per person significantly exceeds the rational consumption of bread and bakery products, then the production and consumption of livestock products, in particular meat and dairy, is insufficient. Thus, the production and consumption of milk and milk products per person in the last 10 years does not exceed respectively $260 \mathrm{~kg}$ and $225 \mathrm{~kg}$. In 2016, milk was produced $243.3 \mathrm{~kg}$ per person, consumed only $209.5 \mathrm{~kg}$, or $55.1 \%$ of the rational consumption rate of $380 \mathrm{~kg}$. Meat of all kinds of animals and meat products statistics are as follows: production per person in recent years ranges from $45 \mathrm{~kg}$ to $55 \mathrm{~kg}$, consumption - from $50 \mathrm{~kg}$ to $54 \mathrm{~kg}$. In
$2016,54.5 \mathrm{~kg}$ of meat was produced per person, $51.4 \mathrm{~kg}$ of meat and meat products were consumed, or only $62 \%$ of the rational science-based norm of $83 \mathrm{~kg}$ [14]. In addition to the lack of production of livestock products, a special feature of the industry is the structure of producers.

The lion's share of meat and dairy products is produced by households, which hold mostly up to five heads of livestock. The share of households in production, for example, of milk is almost $74 \%$ (or 7.7 million tons of production versus 2.7 million tons of milk produced by agricultural enterprises) (Fig. 4); 36\% (or 834,000 tons versus almost $1,490,000$ tons) of meat is produced by households, including beef meat $73,6 \%$, pork $46,9 \%$.

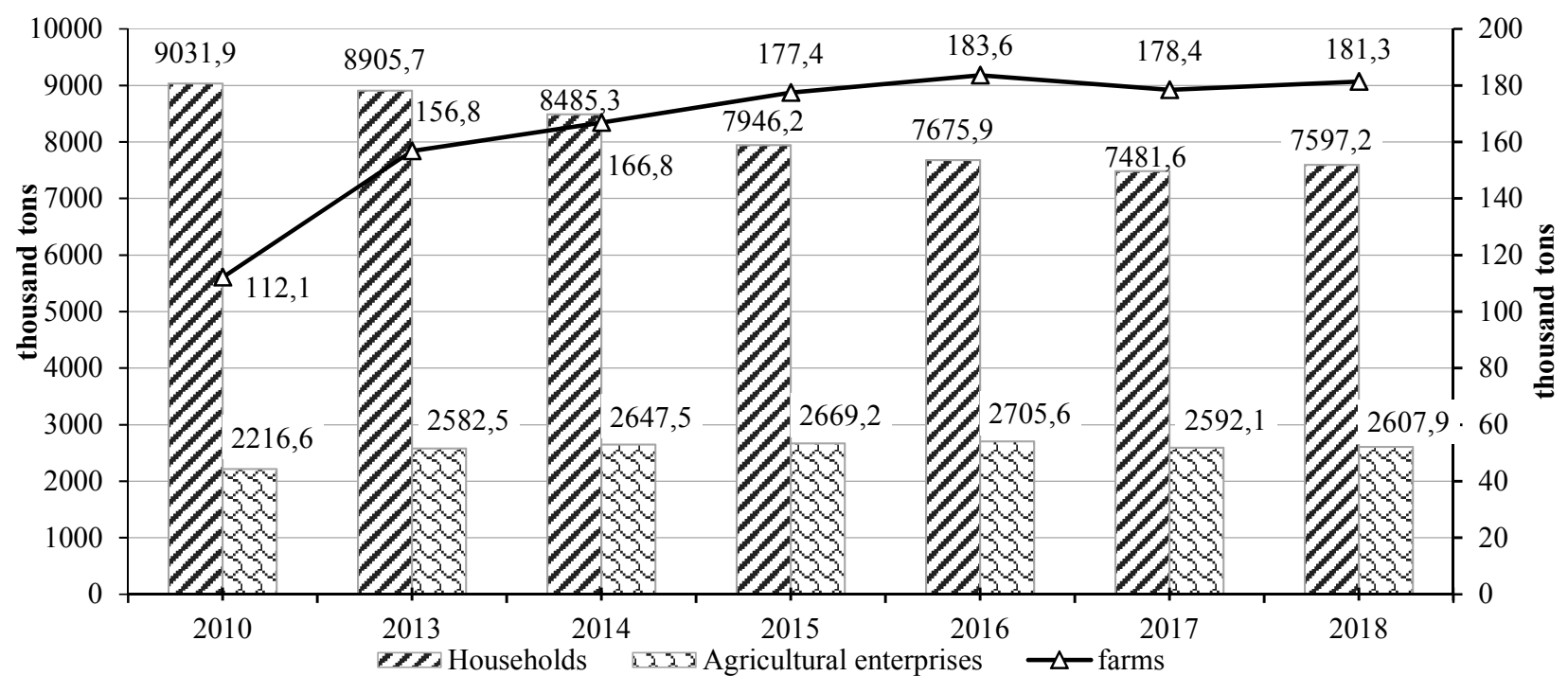

Fig. 4. Milk production in farms of all categories of Ukraine (developed by the authors based on source [14])

In Ukraine, such households of more than 4 million, which qualify for state registration as legal entities or entrepreneurs, are small, socially disadvantaged, do not have access to state support, which lacks the financial capacity to provide automated production of agricultural products, which also are not able to enter the organized market and sell their products to consumers in a civilized way.

Among the important steps that determine the particularities of the national institutional environment in the agricultural sector are the adoption of the National Target Program for the Development of the Ukrainian Village for the period up to 2015, the Strategy for the Development of the Agricultural Sector for the Period until 2020, the Concepts of Public-Private Partnership Development in Ukraine. 2013-2018 and more. Thus, at this stage of agrarian development the institutional mechanism has come to the final phase of functioning preparation of the institutional environment for new transformations.
The qualitatively new period of integration of the institutional environment in the agricultural sector of the economy into the international space is extremely important for the development of the institutional environment. On January 1, 2016, the European Union and Ukraine began applying the provisions of the Deep and Comprehensive Free Trade Area. This is a significant step for the development of the agrarian sector, thus, the prospects for further development of the EU countries market by domestic companies, improving the level of quality, environmental characteristics and safety of Ukrainian agricultural products, improving the state of food security of the country.

According to customs statistics, in 2017, the volume of foreign trade in agricultural products in Ukraine amounted to USD 22.2 billion, which increased by $14 \%$ compared to the previous year. Imports increased by $10 \%$ to USD 4.3 billion. US exports - up $15 \%$ to $\$ 17.9$ billion US and exceeded imports by 4 times. Figure 5 presents the dynamics of Ukraine's foreign trade in agricultural products. 


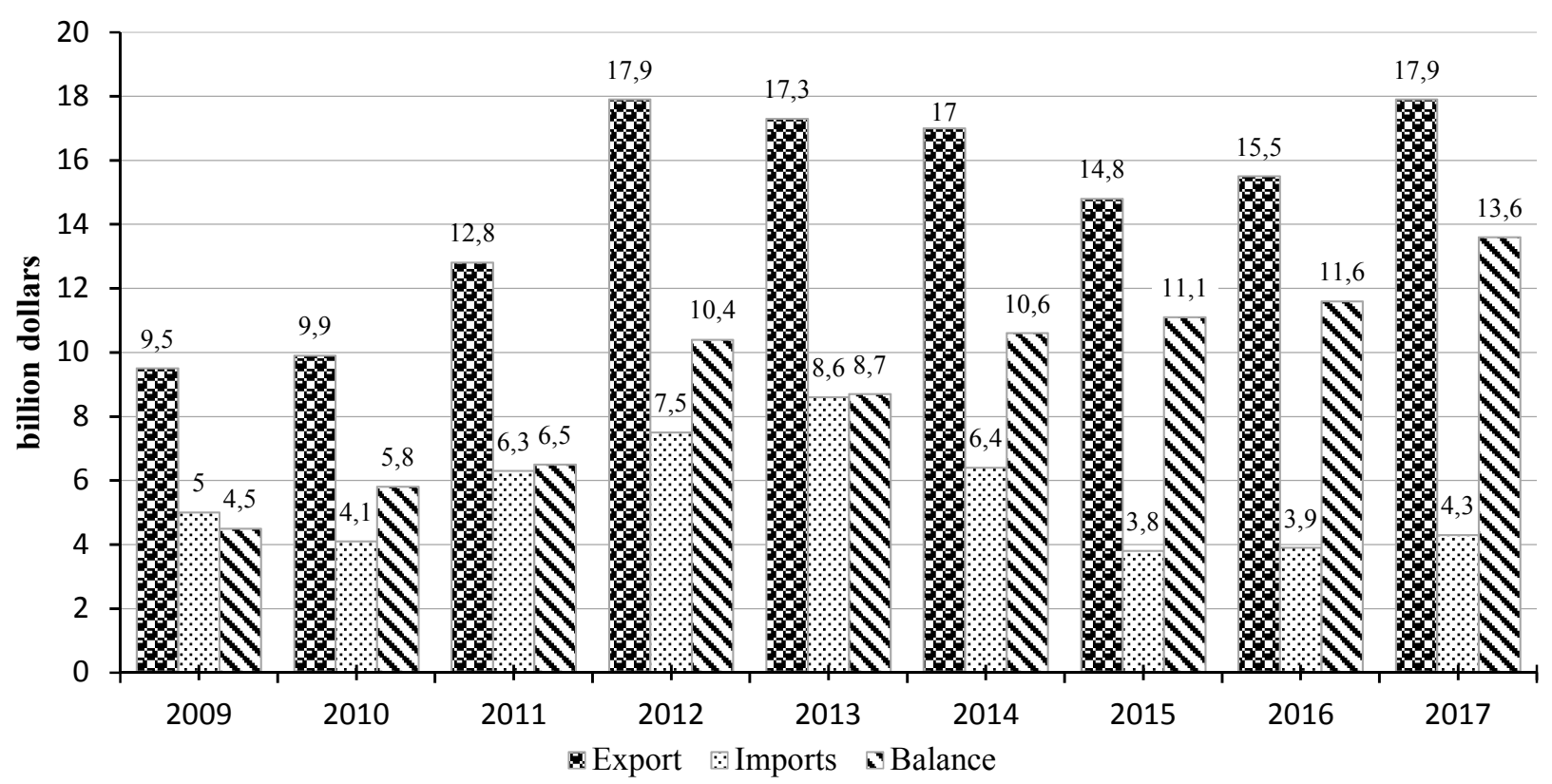

Fig. 5. Dynamics of Ukraine's foreign trade in agricultural products for 2009-2017 [14]

In the course of further development of the agrarian sector there will be organizational and structural changes in the dismantling of some and the acquisition and merger of other farms. At the same time, the types of farms of socio-economic nature will play an important role in determining the effective organizational and economic structure of agricultural enterprises, with the dominant role of private property.

Instead, agroholdings will play a decisive role in shaping this structure and transforming the structure of the agricultural sector of the Ukrainian economy as a whole.

Conclusions. The current stage of agricultural development in Ukraine is accompanied by exacerbation of a number of socio-economic problems.

However, even under adverse conditions, the agrarian sector continues to show acceptable rates of development, which is primarily the result of land and agrarian reforms. In today's context, the institutional matrix of agrarian policy is not formed in Ukraine. Agrarian sector development strategies have been developed and the legislative foundations of agricultural policy are outdated and inconsistent.

The number of regulations envisaging annually a new procedure for allocating budget expenditures to the agricultural sector is not consistent with the strategic priorities of the agricultural sector development, and therefore the effectiveness of such support in solving its current problems is low. At the same time, new challenges require a timely response from the state, agrarian science and practice.

How quickly and effectively the domestic agrarian sector adapts to the new economic conditions depends on its further prospects to occupy a worthy place among the leading producers of agro-food products in the world.

\section{Literature}

1. Бородіна О.М. Інституційний розвиток сільського господарства та села України і Росії та його гармонізація з європейською політичною практикою. Економіка Украӥни. 2012. № 11. С. 48-61. 2. Кириленко І.Г. Аграрна реформа в Україні: надбання, проблеми. Економіка АПК. 2005. № 5. С. 8 - 14. 3. Лупенко Ю.О. Сучасний стан та перспективи міжнародної інтеграції аграрного сектору України: завдання агроекономічної науки. Економіка АПК. 2015. № 6. С. 6 -10. 4. МесельВеселяк В.Я., Федоров М.М. Стратегічні напрями розвитку аграрного сектору економіки України. Економіка АПК. 2016. № 6. С. 37-49. 5. Саблук П.Т. Стан і напрями розвитку аграрної реформи. Економіка АПК. 2015. № 2. С. 10 -17. 6. Зінчук Т. О. Свропейська інтеграція: проблеми адаптації аграрного сектора економіки України: монографія. Житомир : ДВНЗ. «Держ. агроекол. ун-т», 2008. 384 с. 7. Калашнікова Т. В. Удосконалення державної підтримки аграрних підприємств України в умовах глобалізації : монографія. Харків : «Влавке», 2014. 280 с. 8. Кваша С. М. Методологічний базис прийняття суспільних рішень в аграрній політиці. Економіка АПК. 2013. № 8. С. 1221. 9. Попова О. Л. Нові пріоритети Спільної аграрної політики ЄС на 2014-2020 роки: стратегічні орієнтири для розвитку агросфери України. Економіка АПК. 2013. № 12. С. 89-96. 10. Шибаєва Н. В. Формування та реалізація організаційно-економічного механізму регуляторної політики в аграрній сфері. Вісник ХНТУСГ «Економічні науки». Харків: ХНТУСГ. 2017. Вип. 182. С. 266-278. 11. Малік М.Й., Шпикуляк О.Г. Інституціоналізація аграрного підприємництва: трансформація та ефективність. Економіка АПК. 2010. № 7. С. 132-139. 12. Сільське господарство 2016 України (Статистичний збірник). Київ: Державна служба статистики України, 2017. 246 с. 13. Види сільськогоспо- 
дарських підприємств в Україні / Український клуб аграрного бізнесу. URL: http://ucab.ua/ua/doing_agribusi ness/umovi_vedennya_agrobiznesu/vidi_silskogospodars kikh_pidpriemstv_v_ukraini. 14. Кількість сільськогосподарських підприємств / Офіційний сайт державної служби статистики України. URL: http://www.ukrstat. gov.ua/operativ/operativ2016/sg/ $/ \mathrm{ksgp} / \mathrm{ksgp} \_$_u/ksgp_11_2 017u.htm// 15. Про Державний бюджет України на 2018 рік: Закон України від 07 грудня 2017 р. № 2246VIII. URL: http://zakon2.rada.gov.ua/laws/show/2246-1.

\section{References}

1. Borodina O.M. (2012). Instytutsiinyi rozvytok silskoho hospodarstva ta sela Ukrainy i Rosii ta yoho harmonizatsiia $\mathrm{z}$ yevropeiskoiu politychnoiu praktykoiu [Institutional development of agriculture and rural areas of Ukraine and Russia and its harmonization with European political practice]. Ekonomika Ukrainy - Economy of Ukraine, 11, pp. 48-61 [in Ukrainian].

2. Kyrylenko I.H. (2005). Ahrarna reforma v Ukraini: nadbannia, problemy [Agrarian reform in Ukraine: property, problems]. Ekonomika APK, 5, pp. 814 [in Ukrainian].

3. Lupenko Yu.O. (2015). Suchasnyi stan ta perspektyvy mizhnarodnoi intehratsii ahrarnoho sektoru Ukrainy: zavdannia ahroekonomichnoi nauky [Current status and prospects of international integration of the agrarian sector of Ukraine: tasks of agroeconomic science]. Ekonomika APK, 6, pp. 6-10 [in Ukrainian].

4. Mesel-Veseliak V.Ya., Fedorov M.M. (2016). Stratehichni napriamy rozvytku ahrarnoho sektoru ekonomiky Ukrainy [Strategic directions of development of agrarian sector of economy of Ukraine]. Ekonomika $A P K, 6$, pp. 37-49 [in Ukrainian].

5. Sabluk P.T. (2015). Stan i napriamy rozvytku ahrarnoi reformy [State and directions of development of agrarian reform]. Ekonomika APK, 2, pp. 10-17 [in Ukrainian].

6. Zinchuk T. O. (2008). Yevropeiska intehratsiia: problemy adaptatsii ahrarnoho sektora ekonomiky Ukrainy [European integration: problems of adaptation of the agrarian sector of Ukrainian economy]. Zhytomyr, State Agro-ecological University [in Ukrainian].

7. Kalashnikova T. V. (2014). Udoskonalennia derzhavnoi pidtrymky ahrarnykh pidpryiemstv Ukrainy $v$ umovakh hlobalizatsii [Improvement of state support of agrarian enterprises of Ukraine in the conditions of globalization]. Kharkiv, «Vlavke» [in Ukrainian].

8. Kvasha S. M. (2013). Metodolohichnyi bazys pryiniattia suspilnykh rishen $\mathrm{v}$ ahrarnii politytsi [Methodological basis of social decision making in agrarian policy]. Ekonomika $A P K$, 8, pp. 12-21 [in Ukrainian].

9. Popova O. L. (2013). Novi priorytety Spilnoi ahrarnoi polityky YeS na 2014-2020 roky: stratehichni oriientyry dlia rozvytku ahrosfery Ukrainy [New priorities of the EU Common Agricultural Policy for 2014-2020: strategic guidelines for the development of Ukraine's agrosphere]. Ekonomika APK, 12, pp. 89-96 [in Ukrainian].

10. Shybaieva N. V. (2017). Formuvannia ta realizatsiia orhanizatsiino-ekonomichnoho mekhanizmu rehuliatornoi polityky $\mathrm{v}$ ahrarnii sferi [Formation and realization of the organizational and economic mechanism of the regulatory policy in the agrarian sector]. Visnyk KhNTUSH «Ekonomichni nauky» Journal of Kharkov National Technical University of Agriculture Petro Vasilenko "Economic Sciences", Issue 182, pp. 266-278 [in Ukrainian].

11. Malik M.Y., Shpykuliak O.H. (2010). Instytutsionalizatsiia ahrarnoho pidpryiemnytstva: transformatsiia ta efektyvnist [Institutionalization of agrarian entrepreneurship: transformation and efficiency]. Ekonomika $A P K, 7$, pp. 132-139 [in Ukrainian].

12. Silske hospodarstvo 2016 Ukrainy (Statystychnyi zbirnyk) [Agriculture 2016 of Ukraine (Statistical collection)]. Kyiv, State Statistics Service of Ukraine [in Ukrainian].

13. Vydy silskohospodarskykh pidpryiemstv v Ukraini [Types of agricultural enterprises in Ukraine]. Ukrainian Agrarian Business Club. (n.d.). ucab.ua. Retrieved from http://ucab.ua/ua/doing_agribusiness/umovi_vedennya_ag robiznesu/vidi_silskogospodarskikh_pidpriemstv_v_ukrai ni [in Ukrainian].

14. Kilkist silskohospodarskykh pidpryiemstv [Number of agricultural enterprises]. State Statistics Service of Ukraine. ukrstat.gov.ua. Retrieved from http: //www. ukrstat.gov.ua/operativ/operativ2016/sg/ksgp/ksgp_u/ksg p_11_2017u.htm/ [in Ukrainian].

15. Pro Derzhavnyi biudzhet Ukrainy na 2018 rik: Zakon Ukrainy vid 07 hrudnia 2017 r. № 2246-VIII [On the State Budget of Ukraine for 2018: Law of Ukraine of December 07, 2017 No. 2246-VIII]. zakon2.rada.gov.ua. Retrieved from http://zakon2.rada.gov.ua/laws/show/ 2246-1 [in Ukrainian].

Колесников С. О., Мішура В. Б. Розвиток аграрного сектору економіки України: прогнози та перспективи

У статті виявлено сучасні проблеми розвитку аграрного сектору економіки України в умовах інституційних змін. Проаналізовано розвиток аграрної сфери країни в контексті інституційних перетворень. Визначено перспективи розвитку аграрного сектору національної економіки з урахуванням наявних ризиків і можливих варіантів державної політики. Проведено кореляційний аналіз фермерських і нефермерських господарств за період з 2012 по 2018 рік. Таким чином, вивчена залежність Y від Х. На етапі специфікації була обрана парна лінійна регресія. Оцінено піi параметри методом найменших квадратів. Статистична значимість рівняння перевірена за допомогою коефіцієнта детермінації й критерію Фішера. Встановлено, що в досліджуваній ситуації тільки $10.35 \%$ загальної варіабельності Y пояснюється зміною Х. Статистична значимість моделі обумовлена невеликим обсягом вибірки й впливом інших факторів на результативний фактор U. Доведено, що для забезпечення раціонального рівня дотримання сільгосптоваровиробниками агротехнологічних вимог необхідно вжити комплекс заходів, зокрема: запровадити сприятливий режим ввезення імпортованих мінеральних добрив і засобів за- 
хисту рослин; запровадити економічне стимулювання власників землі, землекористувачів та орендарів земельних ділянок за підвищення родючості грунтів і поліпшення їх економічного стану.

Ключові слова: аграрна політика, державна підтримка, сільське господарство, тваринництво, бюджетні витрати, фермерські господарства.

Kolesnikov S., Mishura V. Development of the Agrarian Sector of the Ukrainian Economy: Forecasts and Prospects

In the article the modern problems of development of agrarian sector of economy of Ukraine in the conditions of institutional changes are revealed. The development of the agrarian sphere of the country in the context of institutional changes is analyzed. Prospects for the development of the agricultural sector of the national economy have been determined, taking into account the existing risks and possible options for public policy.

The correlation analysis of farms and non-farms for the period from 2012 to 2018 is conducted. Thus, the dependence of $\mathrm{Y}$ on $\mathrm{X}$ was studied. In the specification step, a pairwise linear regression was chosen. It estimated its least squares parameters. The statistical significance of the equation is verified using the Fisher coefficient and determination. Only $10.35 \%$ of the total variability of $Y$ is found to be explained by the change in X. The statistical significance of the model is due to the small sample size and the influence of other factors on the effective factor $U$. It is proved that to ensure a rational level of compliance of agricultural producers with agro-technological requirements it is necessary to take a set of measures, in particular: to introduce a favorable regime of import of imported mineral fertilizers and means; introduce economic incentives for land owners, land users and land tenants to increase soil fertility and improve their economic condition.

Keywords: agricultural policy, state support, agriculture, animal husbandry, budget expenditures, farms.
Колесников С. А., Мишура В. Б. Развитие аграрного сектора экономики Украины: прогнозы и перспективы

В статье выявлены современные проблемы развития аграрного сектора экономики Украины в условиях институционных изменений. Проанализировано развитие аграрной сферы страны в контексте институционных преобразований. Определены перспективы развития аграрного сектора национальной экономики с учетом имеющихся рисков и возможных вариантов государственной политики. Проведен корреляционный анализ фермерских и нефермерских хозяйств за период с 2012 по 2018 год. Таким образом, изучена зависимость Y от X. На этапе спецификации была избрана парная линейная регрессия. Оценены ее параметры методом наименьших квадратов. Статистическая значимость уравнения проверена с помощью коэффициента детерминации и критерия Фишера. Установлено, что в исследуемой ситуации только 10,35\% общей вариабельности Y объясняется изменением Х. Статистическая значимость модели обусловлена небольшим объемом выборки и влиянием других факторов на результативный фактор U. Доказано, что для обеспечения рационального уровня соблюдения сельскохозяйственными товаропроизводителями агротехнологических требований необходимо применить комплекс мероприятий, в частности: ввести благоприятный режим ввоза импортированных минеральных удобрений и средств защиты растений; ввести экономическое стимулирование владельцев земли, землепользователей и арендаторов земельных участков за повышение плодородия грунтов и улучшение их экономического состояния.

Ключевые слова: аграрная политика, государственная поддержка, сельское хозяйство, животноводство, бюджетные расходы, фермерские хозяйства.

Received by the editors: 30.09 .2019 and final form 19.12.2019 